\title{
Differential Diagnosis of Cortical Blindness, Creutzfeldt-Jakob Disease, Heidenhain Variant
}

\author{
Kortikal Körlüğ̈̈̈n Ayırıcı Tanısı, Creutzfeldt Jakob Hastalığı, Heidenhain Varyantı
}

\author{
(1) Yasemin Dinç1 , (1) Ezgi Sezer Eryıldız², (®) Atilla Özcan Özdemir² \\ ${ }^{1}$ Bilecik State Hospital, Clinic of Neurology, Bilecik, Turkey \\ 2Eskisehir Osmangazi University Faculty of Medicine, Department of Neurology, Eskisehir, Turkey
}

Keywords: Creutzfeldt-Jakob disease, cortical blindness, Heidenhain variant

Anahtar Kelimeler: Creutzfeldt-Jakob hastalığı1, kortikal körlük, Heidenhain varyantı

\section{Dear Editor,}

The etiology of visual loss was investigated in a 58-year-old female patient who was admitted to our ophthalmology clinic. In her eye examination, she had only light perception in both eyes, and the anterior segments and fundi were normal. Bilateral direct and indirect light reflexes were positive. The patient was evaluated by the Neurology Clinic and it was learned that her visual acuity decreased and vision loss started two months ago. The patient stated that she could not drive and could not watch television for this reason. On her examination, she was conscious and fully oriented (place, time, person), she had no paresis, and cranial nerves were intact. There was no nuchal stiffness and her vital signs were stable. Cranial magnetic resonance imaging (MRI) and electroencephalogram (EEG) were normal. Two days later, she was transferred to the Neurology Clinic due to newonset hallucinations and agitation. A lumbar puncture revealed no cells in the cerebrospinal fluid (CSF), but 14.3 .3 protein was positive.

In the following period, the cognition of the patient worsened and the orientation and co-operation deteriorated after 10 days. Follow-up cranial MRI was normal. In the EEG, the basal rhythm was observed to be composed of 5-6 Hz delta waves. There were no cells in the follow-up CSF examination. One week later, an akinetic mutism developed and the myoclonus started. Similar to the previous EEG, the basal rhythm consisted of 5-6 Hz delta waves on the control EEG. MRI revealed increased signal changes on T2 and fluid attenuated inversion recovery-weighted sequences and diffusion restriction on diffusion-weighted sequences in the bilateral caudate and putamen. There was no signal change in apparent diffusion coefficient mapping (Figure 1A, 1B, 1C, 1D). The patient died one year after being discharged from hospital.

One of the interesting clinical presentations of CreutzfeldtJakob disease (CJD) is the Heidenhain variant, which is characterized by isolated visual symptoms including loss of vision, disturbed perception of colors, and hallucinations. The presence of isolated visual symptoms without cognitive decline leads to difficulty in diagnosis (1). In CJD cases, lesions that were observed as hyperintense on T2-weighted images in basal ganglia were described and these signals were associated with astrogliosis (2). Pathologic prion protein (PrPsc) precipitation has been reported in areas with increased signal changes that are evident even in brain structures with normal signals. However, spongiform change and gliosis in different brain regions have not been associated with signal changes in MRI. The association of PrPsc accumulation with MRI changes is unclear and does not seem to be directly related to the pathologic substrate (3).

There is need for further evaluation of the diagnostic role of MRI in cases of spongiform encephalopathy. Cranial MRIs were normal after the onset of visual loss, dementia, and hallucinations in our patient, and bilateral diffusion restriction was observed in the basal ganglia in the follow-up MRI following the akinetic mutism (Figure 1A). Even after the occurrence of the akinetic mutism, no periodic spike waves were observed in the EEG of the patient, and the absence of periodic spike waves is not

Address for Correspondence/Yazışma Adresi: Yasemin Dinç MD, Bilecik State Hospital, Clinic of Neurology, Bilecik, Turkey Phone: +90 5301790512 E-mail: yaseminden87@hotmail.com ORCID ID: orcid.org/0000-0003-0342-5939

Received/Geliş Tarihi: 01.09.2017 Accepted/Kabul Tarihi: 06.12.2017

${ }^{\circ}$ Copyright 2018 by Turkish Neurological Society

Turkish Journal of Neurology published by Galenos Publishing House. 

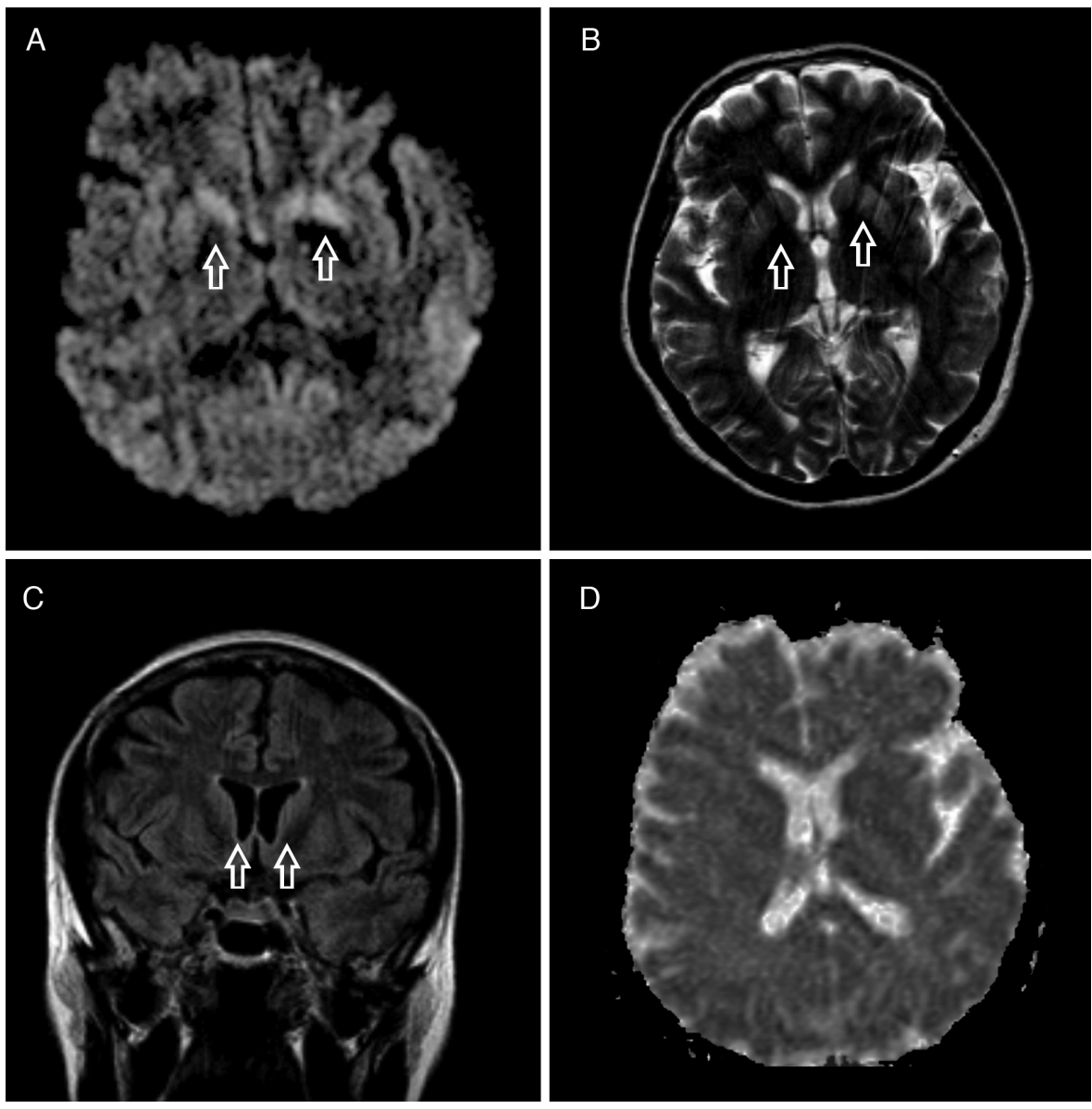

Figure 1. A) Diffusion restriction on diffusion-weighted MRI in caudate and putamen bilaterally, B) Increased signal changes in T2-weighted sequences in caudate and putamen bilaterally, C) Increased signal changes in FLAIR sequences in bilateral caudate and putamen, D) No signal change on cerebral MRI ADC mapping.

exclusionary. It is noteworthy that CSF 14.3 .3 protein positivity along with the clinical status of the patient were the only clues for CJD.

Although rare, the Heidenhain variant of CJD is clinically significant. Initially, most patients present to ophthalmologists. It is not uncommon for neurologists to misdiagnose these patients in their early stages. Physicians should be aware that the Heidenhain variant might occur in atypical cases with slow progression, negative CSF markers, and no specific EEG abnormalities.

\section{Ethics}

Informed Consent: Consent form was filled out by participant.

Peer-review: Internally peer-reviewed.

\section{Authorship Contributions}

Surgical and Medical Practices: Y.D., E.S.E., A.Ö.Ö., Concept: Y.D., E.S.E., A.Ö.Ö., Design: Y.D., E.S.E., A.Ö.Ö., Data Collection or Processing: Y.D., E.S.E., A.Ö.Ö., Analysis or Interpretation:
Y.D., E.S.E., A.Ö.Ö., Literature Search: Y.D., E.S.E., A.Ö.Ö., Writing: Y.D., E.S.E., A.Ö.Ö.

Conflict of Interest: No conflict of interest was declared by the authors.

Financial Disclosure: The authors declared that this study received no financial support.

\section{References}

1. Cooper SA, Murray KL, Heath CA, Will RG, Knight RS. Isolated visual symptoms at onset in sporadic Creutzfeldt-Jakob disease: The clinical phenotype of the "Heidenhain variant". Br J Ophthalmol 2005;89:13411342.

2. Urbach H, Klisch J, Wolf HK, Brechtelsbauer D, Gass S, Solymosi L. MRI in sporadic Creutzfeldt-Jakob disease: Correlation with clinical and neuropathological data. Neuroradiology 1998;40:65-70.

3. Haïk S, Dormont D, Faucheux BA, Marsault C, Hauw JJ. Prion protein deposits match magnetic resonance imaging signal abnormalities in Creutzfeldt-Jakob disease. Ann Neurol 2002;51:797-799. 